Piotr Białucki

Andrzej Ambroziak

Wiesław Derlukiewicz

Artur Lange

Tomasz Bednarek

\title{
Wpływ lutospawania łukowego na właściwości złączy stali ocynkowanej ogniowo
}

\section{Influence of arc braze welding on the properties of joints of dip galvanized steel}

\section{Streszczenie}

W spawaniu grubych elementów pokrytych ogniowo cynkiem częstą praktyką jest mechaniczne usuwanie warstwy cynku i wykonywanie spoin metodą MAG, następnie spoiny oczyszcza się i zabezpiecza warstwą farby antykorozyjnej na bazie cynku, aluminium lub Al-Zn w sprayu. Podczas procesu spawania grubych blach wydziela się tak dużo ciepła, że często ulega uszkodzeniu nawet warstwa cynkowa wewnątrz stalowych profili lub po przeciwnej stronie blach, co wpływa na zmniejszenie odporności korozyjnej części.

W pracy przedstawiono wyniki badań nad lutospawaniem takich części z wykorzystaniem dwóch niskoenergetycznych metod spawania MIG oraz trzech spoiw na bazie miedzi: CuSi3, CuAl8 i CuSn6.

Wykonane złącza lutospawane poddano badaniom wizualnym, wytrzymałościowym, metalograficznym i korozyjnym. Uzyskano złącza bez nadtopienia stali wykazujące wytrzymałość na ścinanie w granicach $305 \div 360 \mathrm{MPa}$ dla spoiw CuSi3 i CuAl8 oraz $208 \div 233 \mathrm{MPa}$ dla spoiwa CuSn.
Abstract

In welding of thick elements covered with fire deposited layer of zinc is common practice the removing of the layer of zinc and then welding of joint by the MAG method. After that joint is cleaned up and is protected by layer of anticorrosive paint on base of zinc, aluminum or $\mathrm{Al}-\mathrm{Zn}$ in spray.

During welding of thick sheet metals arises so a lot of warmth, that the zinc layer undergoes the damage often even the inside steel profiles or on opposite side of sheet metals which influences on decrease the resistance of corrosive part.

The paper presents results of research on soldering of such elements using two low-energy methods of MIG welding and three copper base filler metal, grade CuSi3, CuAl8 and CuSn6.

The completed brazed joints were tested visually and metallographically. Corrosion resistance and shear strength tests were determined also. The obtained joints without melting of steel showed shear strength in the range $305 \div 360 \mathrm{MPa}$ for filler metal CuSi3 and CuAI8 and $208 \div 233$ MPa for CuSn.

\section{Wstęp}

W celu zabezpieczenia stali przed korozją stosuje się powłoki cynkowe. W wielu przypadkach elementy ocynkowane w postaci blach, kształtowników, taśm i rur podlegają łączeniu metodami spawalniczymi. Grubość takich elementów wynosi niejednokrotnie po-

Dr inż. Piotr Białucki, prof. dr hab. inż. Andrzej Ambroziak, dr inż. Wiesław Derlukiewicz, dr inż. Artur Lange, mgr inż. Tomasz Bednarek - Politechnika Wrocławska.

nad $3 \mathrm{~mm}$, a grubość warstwy cynkowej na nich ponad $80 \mu \mathrm{m}$. Zastosowanie tradycyjnych metod spawania łukowego do łączenia blach pokrytych cynkiem stwarza wiele trudności ze względu na intensywne parowanie cynku (temperatura topnienia cynku wynosi $419^{\circ} \mathrm{C}$, a temperatura wrzenia ok. $906^{\circ} \mathrm{C}$ ). Powstające $w$ trakcie spawania pary i tlenki tego metalu prowadzą do tworzenia się w złączu spawanym porów i pustek gazowych, pęknięć, braków przetopu i przyklejeń, łuk jarzy się niestabilnie, a spawany element traci swoje pierwotne właściwości antykorozyjne [1]. 
Powszechnie stosowaną metodą w spawaniu elementów pokrytych ogniowo cynkiem jest mechaniczne usuwanie warstwy cynku, a następnie wykonanie spoin metodą MAG. Na koniec spoiny oczyszcza się i zabezpiecza warstwą cynku, aluminium lub alu-cynku w sprayu. Podczas procesu spawania wydziela się tak dużo ciepła, że często ulega uszkodzeniu nawet warstwa cynkowa wewnątrz stalowych profili lub po przeciwnej stronie blach, co wpływa na zmniejszenie odporności korozyjnej części.

Alternatywą dla procesu spawania MAG jest lutospawanie łukowe metodą MIG. W procesie tym brzegi łączonych blach przygotowuje się jak do spawania, natomiast proces łączenia odbywa się według zasad lutowania twardego, tzn. krawędzie łączonych materiałów nie ulegają nadtopieniu [2]. Lutospawanie metodą MIG/MAG charakteryzuje się małą ilością wprowadzanego ciepła i ograniczonym wpływem na strukturę strefy wpływu ciepła. Jest to możliwe dzięki zastosowaniu spoiw o niskiej temperaturze topnienia, m.in. stopów na osnowie miedzi, np. CuSi3, CuAl8, CuSn6 o zakresie temperatury topnienia odpowiednio: $910 \div 1025^{\circ} \mathrm{C}$, $1030 \div 1040^{\circ} \mathrm{C}$ i $910 \div 1040^{\circ} \mathrm{C}$ oraz dzięki niższym parametrom spawania [3]. Cechą charakterystyczną lutospawania jest wąska strefa wpływu ciepła, która nie powoduje znaczącego zniszczenia powłoki ochronnej jak w przypadku spawania MAG, stosunkowo mała ilość odprysków, stabilne jarzenie się łuku oraz znacznie mniejsza niż przy spawaniu ilość szkodliwych dymów i par.

\section{Charakterystyka warstw cynkowych}

Technologia cynkowania ogniowego wykorzystuje zjawisko dyfuzji, które polega na wnikaniu atomów cynku w zewnętrzną warstwę stali podczas kąpieli w roztopionym cynku. W ten sposób na powierzchni elementu stalowego tworzy się stop żelazowo-cynkowy. Podczas wyjmowania ocynkowanego przedmiotu z kąpieli cynkowej na zewnętrznej powierzchni stopu pozostaje warstwa czystego cynku (rys. 1). Obecność warstw stopowych sprawia, że powłoka cynkowa jest nierozdzielnie związana ze stalowym podłożem. Grubość warstwy cynkowej wynosi $55 \div 100 \mu \mathrm{m}$.

Ogniowa powłoka cynkowa zapewnia nie tylko ochronę bierną jako fizyczna bariera osłaniająca stal, lecz także pełni rolę ochrony elektrochemicznej. Powłoka cynkowa wykonana jest $z$ metalu o bardziej ujemnym potencjale elektrochemicznym (cynk - metal mniej szlachetny) niż metal chroniony (stal). Pokrywanie metali powłokami anodowymi zapewnia chronionemu metalowi ochronę katodową, gdyż powłoka z metalu mniej szlachetnego działa jako anoda. W przypadku pokrywania powierzchni stalowych

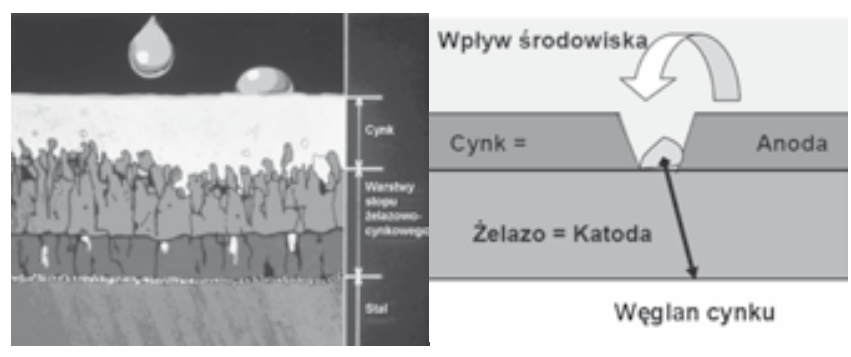

Rys. 1. Struktura warstwy cynkowej o prawidłowej budowie $[4,5]$ Fig. 1. Structure of zinc coatings with correct conformation $[4,5]$

cynkiem w razie pojawienia się nieciągłości (rysy, szczeliny) tworzy się ogniwo, w którym katodą jest żelazo, natomiast anodą cynk. Wtedy do roztworu przechodzą jony cynku, a nie jony żelaza. Tak więc powłoki te nie muszą być zupełnie szczelne. Antykorozyjne właściwości powłok cynkowych polegają na tym, że cynk może tworzyć niezwykle odporne i trudno rozpuszczalne powłoki kryjące. Tworzą się one podczas kontaktu z powietrzem i wodą. Składają się głównie z zasadowego węglanu cynku i to one są odpowiedzialne za właściwą ochronę przed korozją [5].

\section{Charakterystyka lutospawania metodą MIG/MAG}

Lutospawanie łukowe MIG/MAG polega na stapianiu drutu elektrodowego (lutu) na materiał łączony ciepłem łuku spawalniczego, jarzącego się pomiędzy tym drutem a materiałem, w osłonie gazu ochronnego (rys. 2). Lutospoina powstaje w wyniku zwilżenia przez stopione spoiwo powierzchni materiału łączonego podgrzanego ciepłem łuku oraz wzajemnej dyfuzji składników tych materiałów [6].

Nawinięty na szpulę drut elektrodowy (lut) jest podawany za pomocą podajnika drutu w sposób ciągły do obszaru lutospawania. Z uwagi na niezbyt dużą sztywność drutów do lutospawania urządzenia powinny być wyposażone w czterorolkowe podajniki o półokrągłych rowkach rolek prowadzących, dostosowanych do średnicy drutu, oraz zastosowanie w systemie podawania drutu wkładek teflonowych lub wykonanych z materiałów grafitowych [6]. Doprowadzenie prądu do drutu elektrodowego następuje przez styk prądowy. Między końcem drutu elektrodowego a materiałem spawanym jarzy się łuk elektryczny. Roztopiony metal drutu elektrodowego przechodzi do jeziorka lutospoiny. Metal jeziorka lutospoiny, w miarę przemieszczania się łuku w kierunku lutospawania, krzepnąc, tworzy lutospoinę łączącą brzegi elementu lutospawanego. Osłonę metalurgiczną obszaru łuku spawalniczego, ciekłego metalu jeziorka lutospoiny i strefy przylegającej zapewnia doprowadzony przez dyszę gaz osłonowy. Gaz osłonowy może być obojętny chemicznie lub aktywny. 


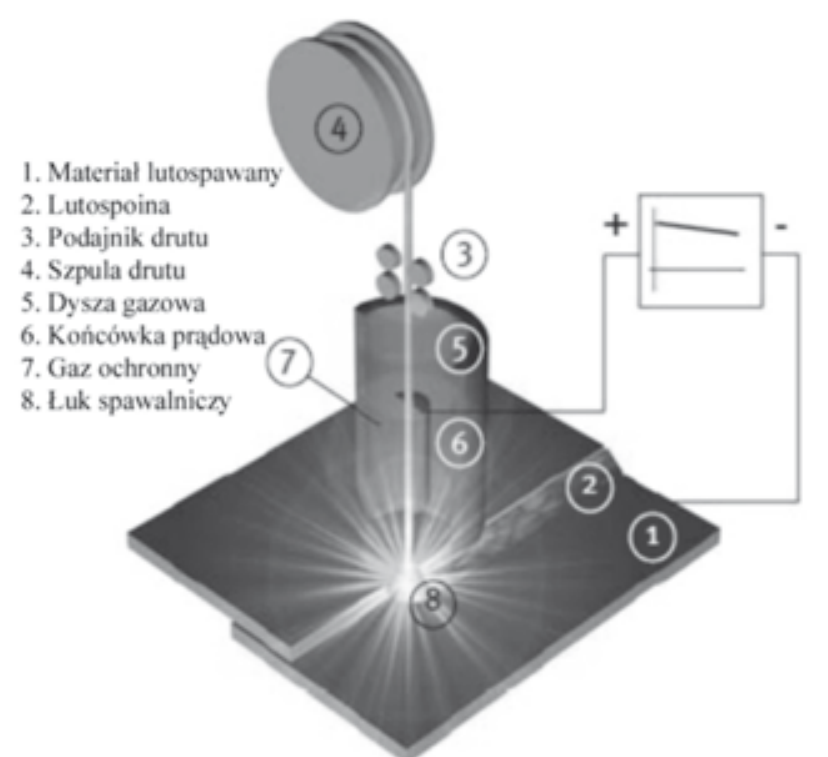

Rys. 2. Schemat lutospawania łukowego w osłonie gazu ochronnego [7]

Fig. 2. Scheme of arc braze welding in shield of protective gas [7]

\section{Materiały dodatkowe do lutospawania}

\section{Spoiwa}

Jako materiały dodatkowe do lutospawania metodą GMAW stosuje się tradycyjnie spoiwa na bazie miedzi, takie jak brązy krzemowe, brązy aluminiowe oraz brązy cynowe. Najczęściej do lutospawania blach ocynkowanych używa się drutu CuSi3. Dzięki możliwości użycia nowoczesnych urządzeń spawalniczych możliwe jest stosowanie również spoiw na bazie cynku.

Firma BEDRA [8] specjalizująca się m.in. w produkcji brązów do lutospawania zaleca w zależności od gatunku stali odpowiedni rodzaj spoiwa (tabl. I). W tablicy II podano zawartość pierwiastków i właściwości tych drutów w zależności od gatunku spoiwa. Firma EWM w materiałach dotyczących wykorzystania metody ColdArc [9] sugeruje wykorzystywanie spoiw na bazie cynku ze względu na niższą temperaturę topnienia spoiw tego typu w stosunku do spoiw na bazie miedzi. Dzięki niższej temperaturze procesu nie występują uszkodzenia w powłoce cynkowej, duże naprężenia i odkształcenia spawalnicze, a wykorzystanie tych spoiw zapewnia dobrą odporność korozyjną. Stwierdzono, że wytrzymałość połączeń lutospawanych blach ocynkowanych o grubości $0,75 \mathrm{~mm}$ z wykorzystaniem spoiwa na bazie cynku jest porównywalna do połączeń lutospawanych spoiwami na bazie miedzi (wytrzymałość połączeń z lutospoiną pachwinową wynosi $340 \mathrm{MPa}$, natomiast doczołowych $200 \mathrm{MPa}$, przy użyciu spoiwa na bazie cynku oraz grubości blachy $0,75 \mathrm{~mm}$ ). Firma GRILLO produkuje druty na bazie cynku w gatunkach: ZnAl2, ZnAl4, ZnAl15 o grubościach: 0,8, $1,0,1,2$ i $1,6 \mathrm{~mm}$ [10]. W tablicy III podano skład chemiczny i wytrzymałość drutów na bazie cynku produkowanych przez polską firmę ZN Silesia.

\section{Gaz osłonowy}

Jako gaz osłonowy $w$ procesach lutospawania GMAW stosuje się przede wszystkim argon (I1 wg PN-EN 14175), a także następujące mieszanki: $\mathrm{Ar}$ $+(1 \div 3) \% \mathrm{CO}_{2}$ (M12 wg PN-EN 14175), $\mathrm{Ar}+1 \% \mathrm{O}_{2}$ (M13 wg PN-EN 14175). Stosowanie mieszanek jako gazu osłonowego zmniejsza napięcie powierzchniowe jeziorka spawalniczego, przez co poprawiają się warunki zwilżania i rozpływania stopionego spoiwa na materiale podstawowym. Zwiększa się stabilność łuku i następuje poprawa wyglądu lica spoiny oraz zmniejsza się ilość odprysków [1]. W tablicy IV podano zalecany gaz osłonowy w zależności od typu spoiwa stosowanego do lutospawania stali ocynkowanych.

Tablica I. Zalecany typ spoiwa w zależności od gatunku lutospawanej stali [8]

Table I. Recommended filler metal type depending on the type of braze welded steel

\begin{tabular}{|c|c|c|c|c|c|c|c|c|c|c|}
\hline \multirow{2}{*}{$\begin{array}{c}\text { Gatunek } \\
\text { stali ocyn- } \\
\text { kowanej }\end{array}$} & \multicolumn{10}{|c|}{ Spoiwo } \\
\hline & SF-Cu & CSSM & COMAS & $\begin{array}{l}\mathrm{Cu}- \\
\text { Si3Mn }\end{array}$ & BS60 & $\begin{array}{l}\text { AlB- } \\
\text { z5Ni2 }\end{array}$ & AlBz8 & $\begin{array}{c}\text { AlB- } \\
\text { z8MNF }\end{array}$ & AlBz9Fe & AlBz9Ni \\
\hline DC 05 & * & * & * & * & * & * & * & * & * & * \\
\hline ZStE180BH & * & * & * & * & * & * & * & * & * & * \\
\hline ZStE340 & & & 0 & * & * & * & * & * & * & * \\
\hline DP600 & & & 0 & 0 & 0 & 0 & 0 & 0 & * & * \\
\hline TRIP700 & & & & & & & & & 0 & 0 \\
\hline
\end{tabular}


Tablica II. Właściwości spoiw na bazie miedzi do lutospawania stali ocynkowanych [8]

Table II. Properties of filler metals based on the cooper used for braze welding of zinc [8]

\begin{tabular}{|c|c|c|c|c|c|c|c|c|c|c|c|c|c|c|}
\hline \multicolumn{2}{|c|}{ Spoiwo } & \multicolumn{9}{|c|}{ Zawartość pierwiastków, \% wag. } & \multicolumn{4}{|c|}{ Właściwości } \\
\hline $\begin{array}{c}\text { Nazwa } \\
\text { handlowa }\end{array}$ & $\begin{array}{c}\text { Gat. } \\
\text { wg normy } \\
\text { DIN } 1733\end{array}$ & $\mathrm{Cu}$ & $\mathrm{Al}$ & Si & Sn & $\mathrm{Mn}$ & $\mathrm{Ni}$ & $\mathrm{P}$ & $\mathrm{Fe}$ & inne & $\begin{array}{l}\text { Temp. } \\
\text { topnie- } \\
\text { nia }\end{array}$ & $\mathrm{R}_{\mathrm{m}}, \mathrm{MPa}$ & $\begin{array}{l}\text { Wydłuże- } \\
\text { nie } A_{5}, \%\end{array}$ & $\begin{array}{c}\text { Twardość } \\
\text { HBW }\end{array}$ \\
\hline $\mathrm{SF}-\mathrm{Cu}$ & $\begin{array}{l}\text { nienormo- } \\
\text { wane }\end{array}$ & baza & & & & & & 0,05 & & & 1080 & 220 & 40 & 50 \\
\hline CSSM & SG-CuSn & baza & & 0,2 & 0,8 & 0,2 & & 0,01 & & $\begin{array}{c}\max . \\
0,5\end{array}$ & $\begin{array}{c}1020 \\
\div 1050\end{array}$ & 220 & 30 & 60 \\
\hline COMAS & $\begin{array}{l}\text { Cu6511(wg } \\
\text { ISO 24373) }\end{array}$ & baza & & 1,8 & 0,2 & 1,0 & & 0,01 & & & $\begin{array}{c}1030 \\
\div 1050\end{array}$ & 285 & 45 & 62 \\
\hline CuSi3Mn & SG-CuSi3 & baza & & 2,9 & & 0,9 & & & & $\begin{array}{c}\max . \\
0,5\end{array}$ & $\begin{array}{c}965 \\
\div 1035\end{array}$ & 350 & 40 & 80 \\
\hline BS60 & $\begin{array}{l}\text { nienormo- } \\
\text { wane }\end{array}$ & baza & & 0,25 & 6,0 & 0,25 & & & & $\begin{array}{c}\max . \\
0,5\end{array}$ & $\begin{array}{c}900 \\
\div 1040\end{array}$ & 359 & 44 & 101 \\
\hline AlBz5Ni2 & $\begin{array}{c}\text { Cu6061 } \\
\text { (wg ISO } \\
24373)\end{array}$ & baza & 5,0 & & & 0,2 & 2,0 & & & $\begin{array}{c}\max . \\
0,5\end{array}$ & $\begin{array}{c}1060 \\
\div 1085\end{array}$ & 353 & 45 & 84 \\
\hline AlBz8 & SG-CuAI8 & baza & 8,0 & & & & & & & & $\begin{array}{c}1030 \\
\div 1040\end{array}$ & 430 & 40 & 100 \\
\hline AlBz8MNF & $\begin{array}{c}\text { SG } \\
-\mathrm{CuAl} 8 \mathrm{Ni2}\end{array}$ & baza & 8,0 & & & 2,0 & 2,0 & & 2,0 & $\begin{array}{c}\max . \\
0,5\end{array}$ & $\begin{array}{c}1030 \\
\div 1050\end{array}$ & 530 & 30 & 140 \\
\hline $\mathrm{AlBz} 9 \mathrm{Fe}$ & $\begin{array}{c}\text { SG } \\
\text {-CuAl10Fe }\end{array}$ & baza & 9,5 & & & & & & 1,2 & $\begin{array}{c}\max . \\
0,5\end{array}$ & $\begin{array}{c}1030 \\
\div 1040\end{array}$ & 500 & 35 & 140 \\
\hline AlBz9Ni & $\begin{array}{c}\text { SG- } \\
\text { CuAl8Ni2 }\end{array}$ & baza & 9,0 & & & 2,0 & 2,5 & & 1,5 & $\begin{array}{c}\max . \\
0,5\end{array}$ & $\begin{array}{c}1030 \\
\div 1050\end{array}$ & 530 & 30 & 150 \\
\hline
\end{tabular}

Tablica III. Właściwości spoiw na bazie cynku do lutospawania [11]

Table III. Properties of filler metals based on the zinc used for braze welding [11]

\begin{tabular}{|c|c|c|c|c|c|c|c|c|c|c|}
\hline \multirow{2}{*}{ Spoiwo } & \multicolumn{7}{|c|}{ Zawartość pierwiastków, \% wag., wg PN-EN ISO 14919} & \multirow{2}{*}{ Wytrzymałość $\mathrm{R}_{\mathrm{m}}$} \\
\cline { 2 - 12 } & $\mathrm{Zn}$ & $\mathrm{Al}$ & $\mathrm{Pb}$ & $\mathrm{Cd}$ & $\mathrm{Pb}+\mathrm{Cd}$ & $\mathrm{Sn}$ & $\mathrm{Fe}$ & $\mathrm{Cu}$ & $\mathrm{Si}$ & \\
\hline ZnAl15 $(\mathrm{LH})$ & $84 \div 86$ & $14 \div 16$ & 0,005 & 0,005 & 0,006 & 0,001 & 0,05 & 0,01 & 0,12 & $180 \div 225$ \\
\hline Zn99,99 $(\mathrm{DH})$ & 99,99 & - & 0,005 & 0,005 & 0,006 & 0,001 & 0,003 & 0,002 & - & $120 \div 145$ \\
\hline
\end{tabular}

Tablica IV. Zalecany gaz osłonowy w zależności od typu spoiwa do lutospawania [12]

Table IV. Recommended shielding gas depending on the type of filler metal for braze welding [12]

\begin{tabular}{|c|c|c|c|c|c|}
\hline \multicolumn{2}{|c|}{ Spoiwo } & \multirow{2}{*}{ Zalecany gaz osłonowy } & \multicolumn{3}{|c|}{ Właściwości wytrzymałościowe spoiwa } \\
\hline $\begin{array}{c}\text { Nazwa } \\
\text { handlowa }\end{array}$ & $\begin{array}{c}\text { Gatunek } \\
\text { wg DIN } 1733\end{array}$ & & $\mathrm{R}_{\mathrm{m}}, \mathrm{MPa}$ & $A_{5}, \%$ & $\mathrm{HB}$ \\
\hline $903 \mathrm{M}$ & SG-CuSi3 & I1 (100\% Ar) & $300 \div 330$ & 40 & $80 \div 90$ \\
\hline $904 \mathrm{M}$ & SG-CuSn12 & I1 (100\% Ar) & 300 & 40 & 110 \\
\hline 906M & SG-CuAl8 & $\begin{array}{l}\left.\text { M13 (Argon }+2 \% \mathrm{O}_{2}\right) \text { lub } \\
\text { M12 (Argon }+2,5 \% \mathrm{CO}_{2} \text { ) }\end{array}$ & 430 & 40 & 150 \\
\hline $911 \mathrm{M}$ & SG-CuSn & $\begin{array}{l}\mathrm{M} 13\left(\text { Argon }+2 \% \mathrm{O}_{2}\right) \text { lub } \\
\mathrm{M} 12\left(\text { Argon }+2,5 \% \mathrm{CO}_{2} \text { ) }\right.\end{array}$ & 200 & 30 & 60 \\
\hline $910 \mathrm{M}$ & SG-CuAl8Ni6 & I1 (100\% Ar) & 590 & 30 & $140 \div 180$ \\
\hline $907 \mathrm{M}$ & SG-CuSn6 & I1 (100\% Ar) & 350 & 30 & 100 \\
\hline
\end{tabular}


Tablica V. Rodzaje źródeł prądu, spoiw oraz parametry spawania użyte do lutospawania badanych próbek [13]

Table V. The types of power sources, filler metals and welding parameters used to for braze welding of tested samples [13]

\begin{tabular}{|c|c|c|c|c|c|c|}
\hline Źródło prądu & Producent & Proces & Spoiwo & $\begin{array}{c}\text { Natężenie prądu, } \\
\text { A }\end{array}$ & $\begin{array}{c}\text { Napięcie łuku } \\
\text { V }\end{array}$ & $\begin{array}{l}\text { Prędkość podawania drutu, } \\
\mathrm{m} / \mathrm{min}\end{array}$ \\
\hline \multirow{2}{*}{$\begin{array}{c}\text { TransPulse } \\
\text { Synergic } \\
2700\end{array}$} & \multirow{2}{*}{ Fronius } & \multirow{2}{*}{$\begin{array}{c}\text { Prąd } \\
\text { pulsujący }\end{array}$} & CuSi3 $\varnothing 1 \mathrm{~mm}$ & $125 \div 135$ & $19,0 \div 20,5$ & 7,0 \\
\hline & & & CuAl8 Ø1 mm & $125 \div 135$ & $18,0 \div 19,5$ & 7,0 \\
\hline \multirow{2}{*}{$\begin{array}{c}\text { Power Wave } \\
405 \mathrm{M}+ \\
\text { LF40 }\end{array}$} & \multirow{2}{*}{$\begin{array}{l}\text { Lincoln } \\
\text { Electric }\end{array}$} & $\begin{array}{l}\text { Power } \\
\text { mode }\end{array}$ & CuAl8 Ø1 mm & $135 \div 145$ & $16,8 \div 17,2$ & 7,5 \\
\hline & & $\begin{array}{c}\text { Prąd } \\
\text { pulsujący }\end{array}$ & CuSn $\varnothing 1,2 \mathrm{~mm}$ & $125 \div 135$ & $14,5 \div 15,0$ & 4,2 \\
\hline
\end{tabular}

\section{Wykonanie złączy próbnych}

Złącza wykonano przy użyciu dwóch różnych źródeł prądu oraz trzech spoiw na bazie miedzi. Rodzaje źródeł prądu, spoiwa oraz parametry lutospawania zestawiono w tablicach V i VI. Złącza zakładkowe wykonano ze stali S235JR z blach o grubości 5 i $3 \mathrm{~mm}$ ocynkowanych ogniowo. Do osłony gazowej zastosowano czysty argon (gat. 4.6) o strumieniu objętościowym $15 \mathrm{dm}^{3} / \mathrm{min}$. Lutospawanie przeprowadzono w pozycji nabocznej (PB) techniką „w lewo”.

Grubość warstwy cynkowej na elementach zmierzono grubościomierzem odrywowym Stylotest. Średnia grubość cynku z pomiarów wynosiła $80 \mu \mathrm{m}$.

Wymiary płyt próbnych przygotowanych wg normy PN EN ISO 9018 [38] oraz wyciętych z nich próbek podano na rysunku 3 .

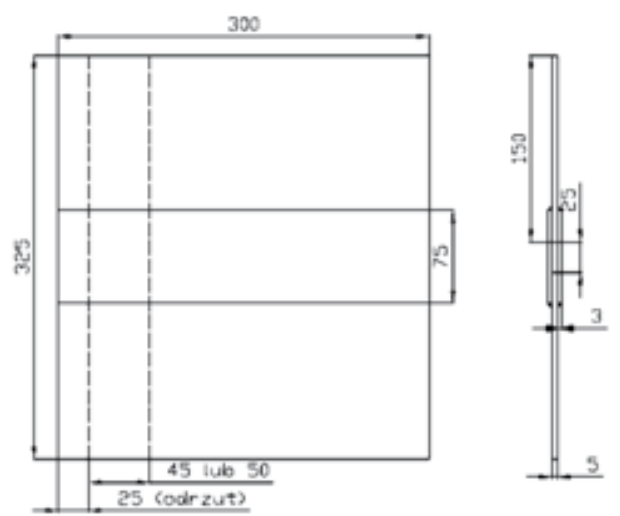

Rys. 3. Wymiary płyt lutospawanych oraz wyciętych próbek

Fig. 3. Sizes of braze welded plates and the test pieces

\section{Badania wizualne}

Badania wizualne przeprowadzono zgodnie $z$ normą PN-EN ISO 17637. Można stwierdzić, że lutospawanie blach ocynkowanych z powłoką o grubości powyżej $80 \mu \mathrm{m}$ nie jest pozbawione odprysku. Najlepszy wynik pod względem małego rozprysku dało lutospawanie drutem CuAl8 w procesie Power Mode (rys. 4a). Oprócz małego rozprysku również lico spoiny jest poprawne, a spoina jest równa i gładka. Lutospawanie drutem CuSn powodowało rozprysk w postaci grubych kropel (rys. 4b).

Na rysunku 5 pokazano przykładowy przełom złącza lutospawanego spoiwem CuSn po próbie rozciągania. Pozostałe przełomy złączy wykonanych spoiwami CuSi3 oraz CuAl8 są do siebie podobne, gdyż pęknięcie nastąpiło w środku lutospoiny.

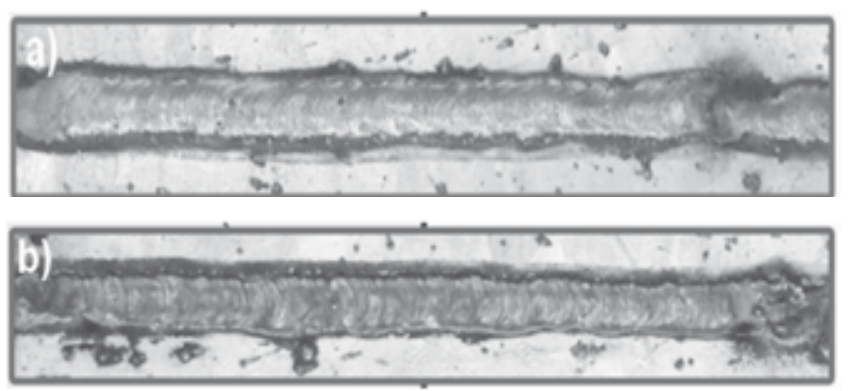

Rys. 4. Lica lutospoin z procesu Power Mode wykonanych drutami: a) CuAl8, b) CuSn

Fig. 4. The appearance of the face of braze welds from the process of Power Mode and with filler metal: a) CuAl8, b) CuSn

Tablica VI. Właściwości spoiw użytych do lutospawania [8]

Table VI. The properties filler metals used for braze welding [8]

\begin{tabular}{|c|c|c|c|c|c|c|c|c|c|c|c|c|c|}
\hline \multirow{2}{*}{$\begin{array}{c}\text { Typ spoiwa } \\
\text { wg DIN } 1733\end{array}$} & \multicolumn{9}{|c|}{ Zawartość pierwiastków, \% wag. } & \multicolumn{4}{|c|}{ Właściwości } \\
\hline & $\mathrm{Cu}$ & Al & $\mathrm{Si}$ & Sn & $\mathrm{Mn}$ & $\mathrm{Ni}$ & $\mathrm{P}$ & $\mathrm{Fe}$ & inne & $\begin{array}{c}\text { Temp. } \\
\text { topnienia }\end{array}$ & $\begin{array}{c}R_{\mathrm{m}} \\
\mathrm{MPa}\end{array}$ & $\begin{array}{c}\text { Wydłużenie } \\
\text { A, \% }\end{array}$ & $\begin{array}{c}\text { Twardość } \\
\text { HBW }\end{array}$ \\
\hline SG-CuSn & baza & & 0,2 & 0,8 & 0,2 & & 0,01 & & $\begin{array}{c}\max . \\
0,5\end{array}$ & $1020 \div 1050$ & 220 & 30 & 60 \\
\hline SG-CuSi3 & baza & & 2,9 & & 0,9 & & & & $\begin{array}{c}\max . \\
0,5\end{array}$ & $965 \div 1035$ & 350 & 40 & 80 \\
\hline SG-CuAl8 & baza & 8,0 & & & & & & & & $1030 \div 1040$ & 430 & 40 & 100 \\
\hline
\end{tabular}




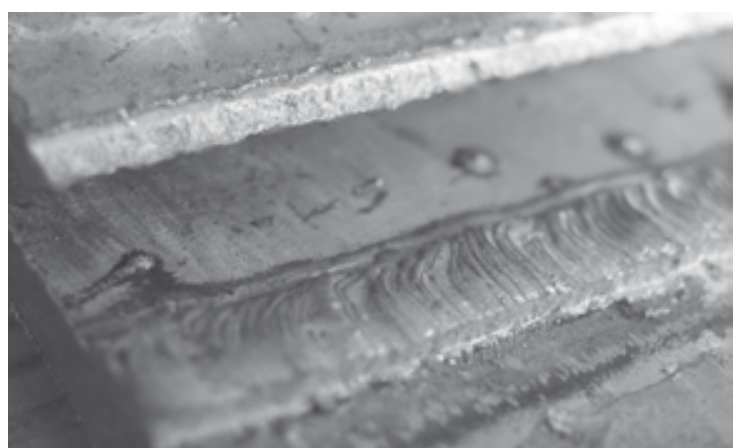

Rys. 5. Powierzchnia przełomu złącza lutospawanego drutem CuSn po próbie rozciągania

Fig. 5. Appearance of the fracture surface after the tensile test of joint braze welded using CuSn filler metal

\section{Próby wytrzymałościowe}

Statyczną próbę ścinania zakładkowych złączy lutospawanych wykonano przez rozciąganie na maszynie wytrzymałościowej Louis Schopper w zakresie pomiarowym do $100 \mathrm{kN}$. Przykładową próbkę przed i po rozciąganiu pokazano na rysunku 6.

Wyniki prób rozciągania złączy zakładkowych zamieszczono w tablicy VII. Wytrzymałość złączy lutospawanych spoiwem CuSi3 wynosiła $314 \div 325 \mathrm{MPa}$, spoiwem CuAl8 - 305 $\div 360 \mathrm{MPa}$, a spoiwem CuSn -

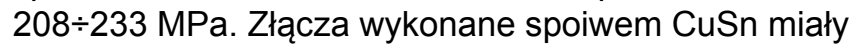
najmniejszą wytrzymałość na ścinanie, natomiast wykonane spoiwami CuAl8 i CuSi3 miały wytrzymałość porównywalną.

Jak widać $z$ rysunku $6 b$, w próbce poza lutospoiną występowało przewężenie $w$ materiale rodzimym, a w niektórych próbkach złom następował poza lutospoiną (rys. 7).

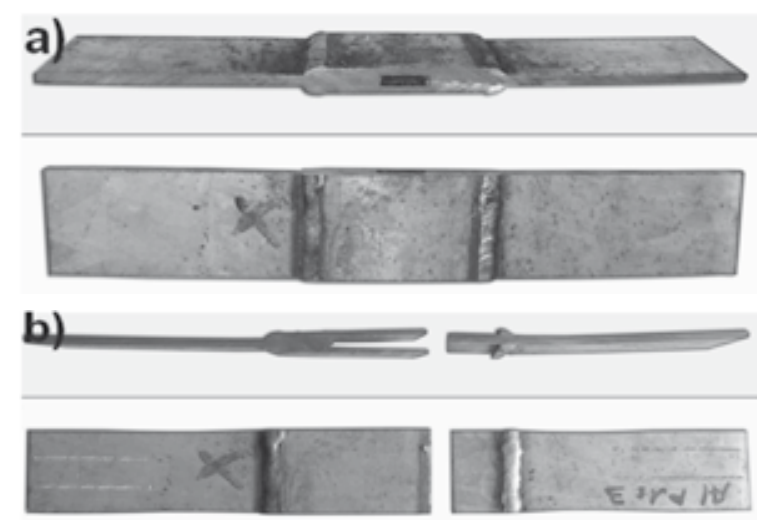

Rys. 6. Próbka złącza lutospawanego spoiwem CuAl8: a) przed próbą rozciągania, b) po próbie rozciągania

Fig. 6. Sample joints braze welded using filler metal CuAl8: a) before tensile test, b) after tensile test

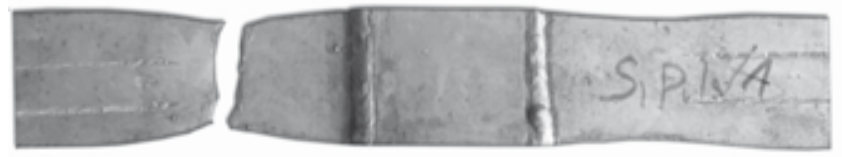

Rys. 7. Próbka rozciągana z przełomem poza lutospoiną z CuSi3 Fig. 7. Sample after tensile test with fracture beyond braze weld of the CuSi3

\section{Badania metalograficzne}

Do badań metalograficznych wytypowano sześć złączy wyciętych z sześciu lutospawanych płyt. Złącza do badań makroskopowych trawiono odczynnikiem Adlera, a do badań mikroskopowych 3\% Nitalem. Obserwację makrostruktur złączy lutospawanych wykonano na mikroskopie świetnym Olympus SZX7 przy powiększeniu $10 \div 50 x$, natomiast obserwacje mikroskopowe

Tablica VII. Wyniki prób wytrzymałości na ścinanie złączy lutospawanych [13]

Table VII. Results of the shear strength tests of braze welded joints [13]

\begin{tabular}{|c|c|c|c|c|}
\hline Oznaczenie próbki & $\begin{array}{c}\text { Powierzchnia przekroju } \\
\text { początkowego próbki, } \mathrm{mm}^{2}\end{array}$ & Wartość siły obciążenia, N & $\begin{array}{c}\text { Wytrzymałość złącza } \\
\mathrm{R}_{\mathrm{t}}, \mathrm{MPa}\end{array}$ & $\begin{array}{c}\text { Miejsce zerwania } \\
\text { próbki }\end{array}$ \\
\hline \multicolumn{5}{|c|}{ Spoiwo CuAl8, TransPulse Synergic 2700 (prąd pulsujący) } \\
\hline Al. Puls1 & 259,29 & 81420 & 314,01 & spoina \\
\hline Al. Puls1 & 259,81 & 79340 & 305,38 & spoina \\
\hline Al. Puls3 & 259,29 & 82170 & 316,91 & spoina \\
\hline \multicolumn{5}{|c|}{ Spoiwo CuSi3, TransPulse Synergic 2700 (prąd pulsujący) } \\
\hline Si Puls1 & 252,50 & 82230 & 325,66 & materiał \\
\hline Si Puls2 & 262,41 & 82390 & 313,98 & spoina \\
\hline \multicolumn{5}{|c|}{ Spoiwo CuAl8, Power Wave 405M + LF40 (Power Mode) } \\
\hline Al. Linc1 & 229,00 & 80900 & 353,28 & materiał \\
\hline Al. Linc2 & 228,50 & 81000 & 354,49 & materiał \\
\hline Al. Linc3 & 233,31 & 78600 & 336,89 & spoina \\
\hline Al. Linc4 & 224,00 & 80800 & 360,71 & materiał \\
\hline \multicolumn{5}{|c|}{ Spoiwo CuSn, Power Wave 405M + LF40 (prąd pulsujący) } \\
\hline Sn Linc1 & 232,79 & 48500 & 208,34 & spoina \\
\hline Sn Linc2 & 233,31 & 52660 & 225,71 & spoina \\
\hline Sn Linc3 & 232,79 & 54000 & 231,97 & spoina \\
\hline Sn Linc4 & 233,83 & 54510 & 233,12 & spoina \\
\hline
\end{tabular}


przeprowadzono na mikroskopie Olympus CK40M przy powiększeniach 100 i 500x. Na rysunkach 8 i 9 pokazano przykładowe makro- i mikrostruktury złączy lutospawanych spoiwami CuAl8 i CuSi3.

Struktury badanych złączy lutospawanych wykazały poprawną budowę, wolną od niezgodności wewnętrznych, stopiwo dobrze zwilżyło powierzchnie łączonych części bez nadtopienia stali. Mikrostrukturę materiału podstawowego stanowi drobnoziarnista struktura ferrytu z małą ilością perlitu, natomiast w strefie wpływu ciepła przy linii zwilżenia występuje gruboziarnista struktura przegrzanego materiału. Mikrostruktura lutospoiny wykonana zarówno drutem CuSi3, jak i CuAl8 oraz CuSn ma charakter dendrytyczny w układzie ziaren ukierunkowanym zgodnie $\mathrm{z}$ gradientem temperatury. Strefa wpływu ciepła dla wszystkich złączy była wąska, przy czym najszerszą strefą cechowały się złącza ze spoiwem CuAl8.

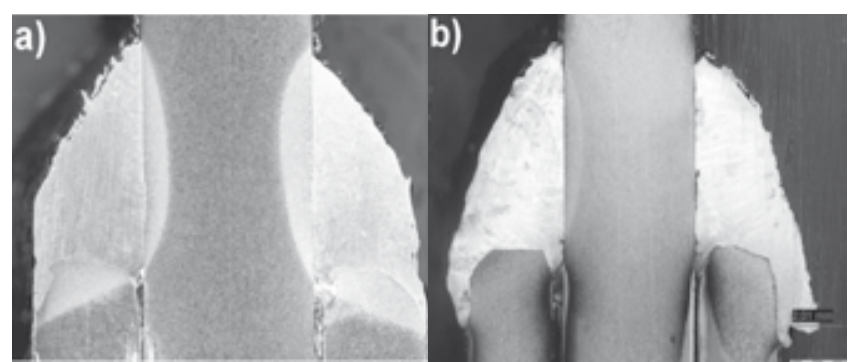

Rys. 8. Makrostruktury złączy lutospawanych: a) spoiwem CuAl8, b) spoiwem CuSi3

Fig. 8. Microstructure of braze welded joints using filler metals: a) $\mathrm{CuAl} 8$, b) $\mathrm{CuSi} 3$

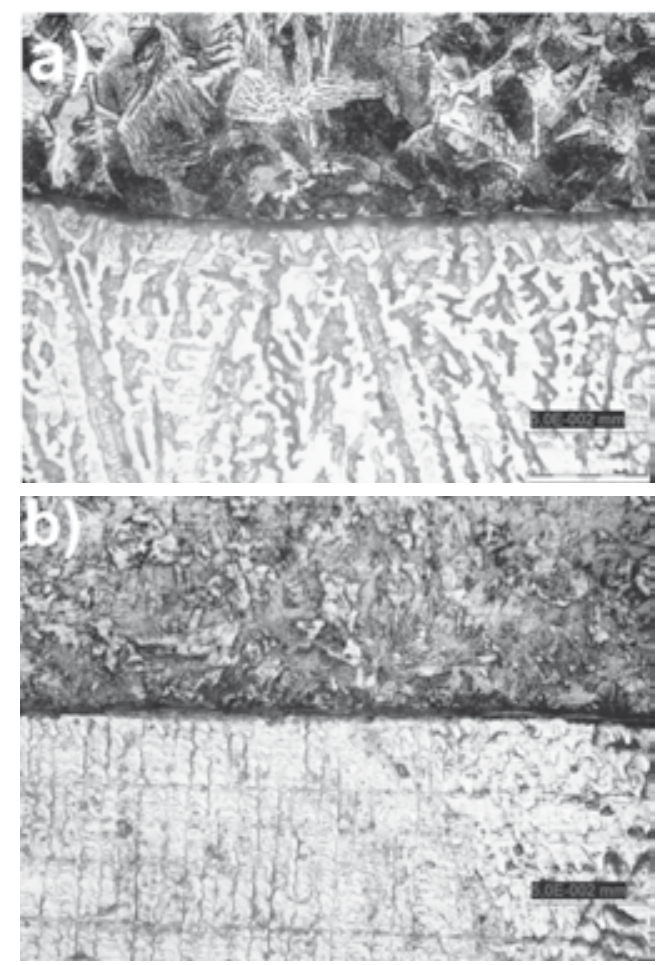

Rys. 9. Mikrostruktury strefy przejściowej złączy lutospawanych: a) spoiwem CuAl8, b) spoiwem $\mathrm{CuSi3}$

Fig 9. Microstructures of the transition zone of braze welded joints using filler metals: a) CuAl8, b) CuSi3

\section{Badania korozyjne}

Badania korozyjne wykonano w komorze solnej Heraeus Vötsch 1000 pokazanej na rysunku 10, wg warunków określonych w PN-EN ISO 9227 [14].

Badanie polegało na ciągłym rozpylaniu $5 \%$ roztworu chlorku sodu w temperaturze $35^{\circ} \mathrm{C}$ w ciągu $480 \mathrm{~h}$. Czas ten odpowiada 5-letniemu narażeniu badanego obiektu na korozję w warunkach atmosferycznych. Na złącza próbne użyto płaskowników o grubości $4 \mathrm{~mm}$ ocynkowanych ogniowo, które zostały połączone lutospoiną czołową spoiwami CuSn, CuAl8 i CuSi3 (rys. 11).

Ponadto wykonano złącza próbne z profili kwadratowych o grubości $5 \mathrm{~mm}$ połączonych lutospoiną pachwinową z profilem ceowym o grubości $3 \mathrm{~mm}$ i budowie takiej, jaka występuje w konstrukcjach rzeczywistych, np. w elementach ogrodzeń budowlanych.

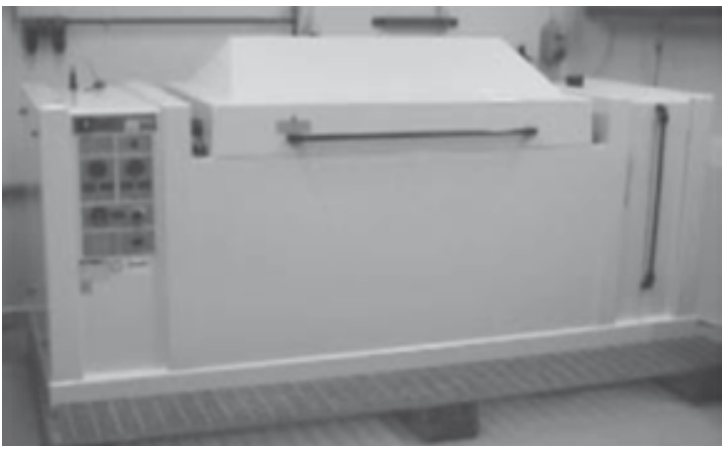

Rys. 10. Komora solna Heraeus Vötsch 1000

Fig. 10. Heraeus Vötsch 1000 salt chamber

a)

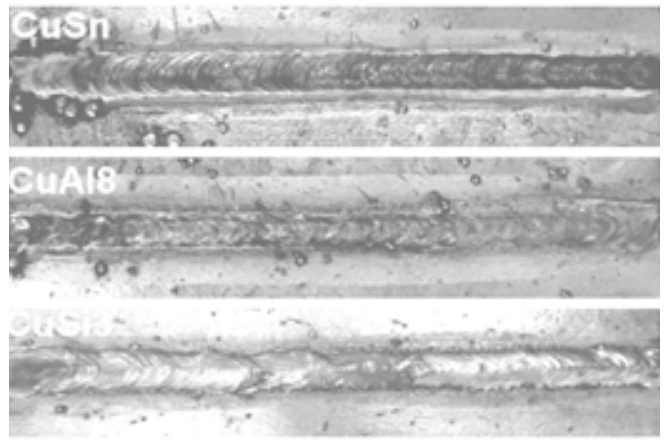

b)
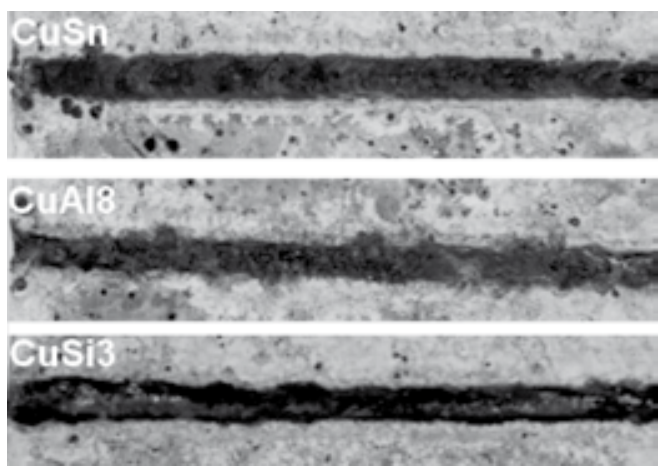

Rys. 11. Złącza doczołowe lutospawane do badań korozyjnych: a) przed badaniami, b) po badaniach

Fig. 11. Appearance of butt joints braze welded for corrosion resistance tests: a) before the tests, b) after the tests 
a)

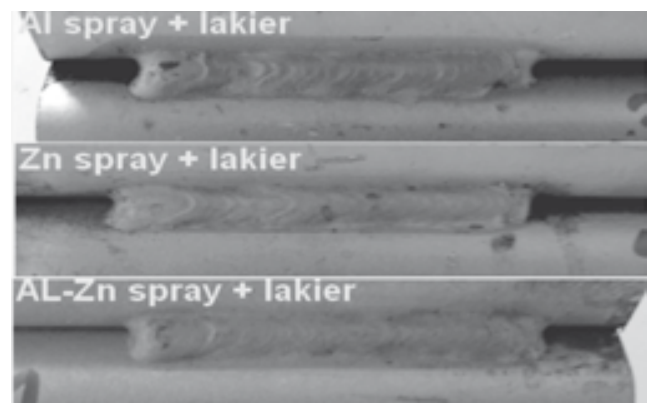

b)

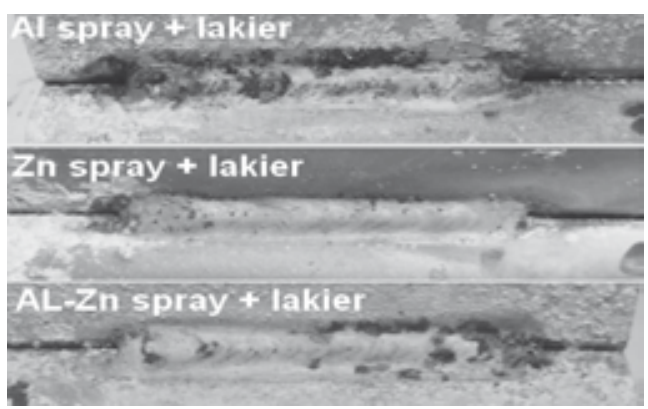

Rys. 12. Złącza spawane metodą MAG spoiwem G3S1 pokryte farbami w sprayu: przed próbą korozyjną, b) po próbie korozyjnej

Fig. 12. MAG welded joints with a G3S1 filler metal protected by layer of anticorrosive paint: a) before the corrosion test, b) after corrosion test

Celem porównania właściwości korozyjnych złączy lutospawanych z właściwościami złączy spawanych i zabezpieczanych farbami antykorozyjnymi wykonano także złącza metodą MAG spoiwem G3S1 pokryte następnie farbami w sprayu (rys. 12a).

W wyniku przeprowadzonych badań korozyjnych złączy lutospawanych nie stwierdzono wyraźnych różnic w odporności korozyjnej zależnej od rodzaju użytego spoiwa. Przedstawiony na rysunku 11b wygląd złączy lutospawanych po próbie korozyjnej wskazuje, że najlepsze właściwości wykazały złącza łączone spoiwem CuSn. Złącze jest wolne od śladów korozji stali, co może świadczyć o tym, że warstwa cynku nie uległa dużym zmianom spowodowanych ciepłem spawania. W przypadku próbek łączonych spoiwami CuAl8 i CuSi3 wystąpiły ślady korozji stali przy lutospoinie, przy czym wyraźnie większe uszkodzenia korozyjne wykazały próbki ze spoiwem CuAl8.

Natomiast wyraźne różnice w odporności korozyjnej uzyskano w przypadku złączy spawanych metodą MAG spoiwem G3S1zabezpieczonych farbą antykorozyjną, których próbki pokazano na rysunku 12 . Z badań wynika, że stosowanie farb antykorozyjnych na bazie aluminium lub mieszanki aluminium z cynkiem słabo zabezpiecza spoinę przed korozją w warunkach występujących w komorze solnej. Najlepsze zabezpieczenia złącza spawanego uzyskano dla pokrycia farbą na bazie cynku w sprayu (rys. 12b).

\section{Podsumowanie}

Proces lutospawania przeprowadzono przy łączeniu blach ze stali S235JS ocynkowanych ogniowo warstwą cynku o grubości większej niż $80 \mu \mathrm{m}$ przy użyciu trzech spoiw: CuSi3, CuAl8 i CuSn oraz zastosowaniu dwóch metod niskoenergetycznych spawania MIG.

W wyniku badań złączy lutospawanych stwierdzono, że rodzaj użytego spoiwa i rodzaj źródła prądu mają wpływ na właściwości złączy. Wytrzymałość na ścinanie złączy zakładkowych wykonanych spoiwem CuSi3 wynosiła od 314 do $325 \mathrm{MPa}$, spoiwem CuAl8 od 305 do $360 \mathrm{MPa}$, natomiast spoiwem CuSn była najniższa i mieściła się w przedziale od 208 do $233 \mathrm{MPa}$. Wykonane badania wskazuja na dużą wytrzymałość takich złączy, a otrzymane wyniki są porównywalne z przytaczanymi w literatury technicznej.

Niewątpliwą wadą lutospawania grubych (powyżej $3 \mathrm{~mm}$ ) blach ocynkowanych ogniowo jest rozprysk, którego nie udało się uniknąć w badanych złączach mimo stosowania trzech różnych spoiw, dwóch rodzajów źródeł prądu i zmian parametrów spawania. Nierówna i gruba warstwa cynku nałożonego ogniowo powoduje niestabilność łuku spawalniczego oraz powstawanie dużej ilości parującego cynku, który powoduje rozprysk stopiwa. Najbardziej estetyczny wygląd złączy z najmniejszą ilością rozprysków uzyskano, stosując spoiwo CuAl8 w procesie Power Mode.

Badania metalograficzne wykazały prawidłową budowę złączy lutospawanych dla wszystkich badanych spoiw i źródeł prądu. Połączenie nastąpiło w wyniku zwilżenia powierzchni lutospawanych ciekłym stopiwem, powierzchniowej dyfuzji i rozpuszczenia warstwy cynku bez nadtopienia powierzchni stali.

Badania odporności na korozję, wykonane w komorze solnej wykazały, że dla wszystkich złączy odporność korozyjnajestniezadowalająca. Wynika to z faktu, że ciepło lutospawania grubych blach $z$ warstwą cynku naniesioną ogniowo powoduje częściowe odparowanie cynku na brzegu lutospoiny, przez co zmniejsza się odporność korozyjna całego złącza.

Najlepszą odporność na korozję wykazały złącza wykonane spoiwem CuSn, lecz miały one najmniejszą wytrzymałość na ścinanie. Brzegi lutospoiny były wolne od śladów korozji, co może świadczyć o tym, że warstwa cynku nie uległa dużym uszkodzeniom od ciepła lutospawania.

$Z$ badań odporności na korozję złączy spawanych metodą MAG spoiwem G3S1 i następnie chronionych farbami wynika, że najlepsze zabezpieczenia złącza spawanego można uzyskać przy pokryciu go farbą na bazie cynku w sprayu.

Przeprowadzone badania wykazują, że lutospawanie grubych blach stalowych pokrytych ogniowo warstwą cynku o grubości powyżej $80 \mu \mathrm{m}$ spełnia warunki wytrzymałościowe, lecz nie daje złączy o wymaganej estetyce i odporności na korozję. 


\title{
50 lat Instytutu Technologii Maszyn i Automatyzacji Politechniki Wrocławskiej
}

\author{
Praca zbiorowa pod red. Zbigniewa Mirskiego
}

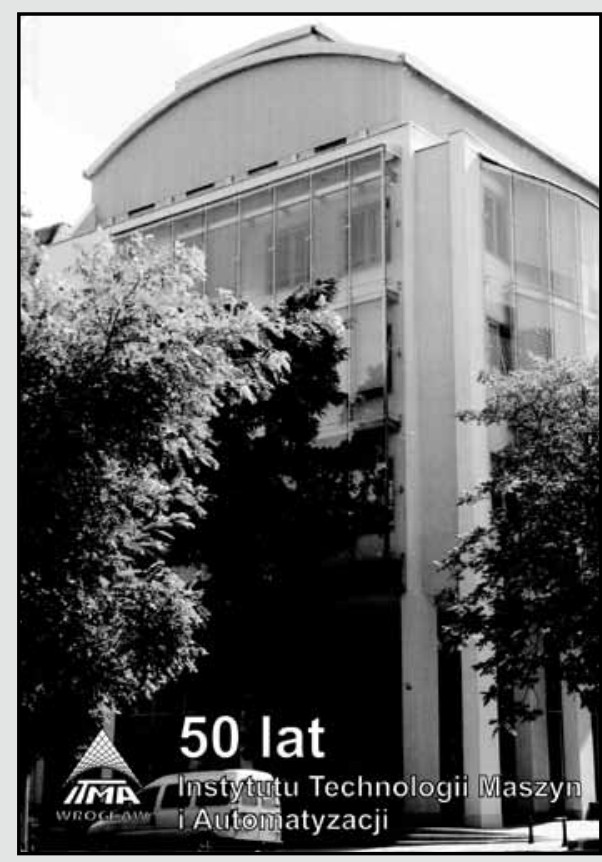

Liczba stron: 198

Oprawa: twarda

Format: B5

Rok wydania: 2013

ISBN 978-83-917677-8-8

Wydawnictwo: Oficyna Wydawnicza

Politechniki Wrocławskiej
Powstała pod redakcją Profesora Zbigniewa Mirskiego publikacja $\mathbf{5 0}$ lat Instytutu Technologii Maszyn i Automatyzacji została wydana z okazji obchodzonego w tym roku jubileuszu 50.-lat istnienia Instytutu. Stanowi ona cenne kompendium wiedzy historycznej na temat Instytutu, która często umyka rozproszona pomiędzy wieloma dokumentami. Wskazane zostało to nawet w pierwszym rozdziale: Uroczystości 40-lecia Instytutu były obchodzone niedawno, 5 lat temu w 2008 r., ale wynikało to z braku dokumentów źródłowych do których dotarto obecnie.
Zebrane w opracowaniu informacje pokazują jak rozwijał się przez ostatnie pół wieku Instytut pod względem struktury organizacyjnej i składu osobowego, dostosowując się zarazem do zmieniającej rzeczywistości. Niezwykle ciekawe są wspomnienia dotychczasowych dyrektorów, którzy zarówno jako pracownicy, jak i osoby nim zarządzające przyczyniły się swoimi decyzjami do osiągnięcia obecnej pozycji Instytutu. Przedstawiono dorobek naukowy poszczególnych zakładów i laboratorium oraz kierunki obecnie prowadzonej działalności badawczo-rozwojowej.

Czytając to opracowanie zachęcam do refleksji nad naszym intelektualnym wpływem na cywilizację przez rozwój nauki i techniki, której celem jest tworzenie technologii przemysłowych o najwyższym standardzie światowym - Profesor Zbigniew Gronostajski - obecny Dyrektor Instytutu.

Opracowat: Lechosław Tuz

\section{Literatura (dokończenie ze str. 27)}

[1] Różański M.: Lutospawanie MIG/MAG blach ocynkowanych i przykłady trudno spawalnych układów materiałowych. Przegląd Spawalnictwa, nr 9/2007, s. 7-12.

[2] Ferenc K.: Spawalnictwo, WNT, Warszawa 2007.

[3] Gruszczyk A.: Odporność korozyjna połączeń lutospawanych stali ocynkowanej. Przegląd Spawalnictwa, nr 9/2007, s. 32-36.

[4] www.mss-schweisstechnik.de/.../Prospekt_TPS_2700_40,0006,2251. pdf 03.04 .10

[5] www.cynkowanie.com.pl 15.03.2010

[6] Gawrysiuk W.: Charakterystyka technologii lutospawania łukowego MIG/MAG, Przegląd Spawalnictwa, nr 2-3/2005, s. $17-20$.

[7] www.schmid-schweissen.ch/docs/Schweisserwissen/broschuere_coldArc.pdf 03.04.10
[8] www.bedra.com/e280/e286/.../BED_bercoweld_rz_22_01_ eng.pdf 03.04.10

[9] www.bentsen-design.com/Tbentsenas/ColdArc.pdf 03.04.10

[10] www.grillo.de/index.php?id=57\&L=2 03.04.10

[11] www.huta-olawa.com.pl/_upload/pliki/drutpl.pdf 03.04.10

[12] www.chem-weld.com/PDF/mig-mag-schweissdraht.pdf 04.04.10

[13] Bednarek T.: Badania właściwości złączy lutospawanych ze stali ocynkowanych ogniowo, Praca dyplomowa, Wydział Mechaniczny. PWr, 2010, promotor dr inż. P. Białucki.

[14] PN-EN ISO 9227.:2007 Badania korozyjne w sztucznych atmosferach. Badania w rozpylonej solance. 